IRENA PRZYBYLSKA

Uniwersytet Śląski

w Katowicach

\title{
EMANCYPACYJNE CZY INSTRUMENTALNE - (RE)KONSTRUKCJA KSZTAŁCENIA KOMPETENCYJNEGO
}

\begin{abstract}
Przybylska Irena, Emancypacyjne czy instrumentalne - (re)konstrukcja kształcenia kompetencyjnego [Emancipatory or Instrumental - (Re)Construction of Competence-Based Education]. Studia Edukacyjne nr 41, 2016, Poznań 2016, pp. 131-156. Adam Mickiewicz University Press. ISSN 12336688. DOI: $10.14746 /$ se.2016.41.9
\end{abstract}

The main aim of the text is to (re)construct competence education in the context of three orientations: technical, humanistic and critical. Competences are discussed as practical and epistemological categories. It is a complex term, which carries the risk of simplification of meaning and structure.

In the instrumental (technical) perspective, competences are reduced to skills and education to behavioural teaching. Due to reconstruction of competences in the context of humanistic orientation, concentration on a person and the process of "becoming" shifted the focus from "effects" of educational influence to the process of development and learning itself. Following this approach, education is not necessarily a process of acquiring competences, but rather a process of their exploration, creation and extension. Individuals will not be able to develop competences if they do not participate in the process of learning.

The source of third, critical orientation, lies in progressivism, cognitive psychology, critical thought, and functional epistemology. Reconstruction is based, among others, on thoughts of Jurgen Habermas, Lawrence Kohlberg and Maria Czerepaniak-Walczak. In this orientation, competences have to be understood in a dynamic way. They are rather an open, cognitive structure which is subjected to constant reorganisation than a set of skills, knowledge or attitudes. The development of competences can be identified with progress to higher levels of development, enabling broadening of both cognitive and individual competences.

The author intends to advocate for critical and emancipatory dimensions of competence-based learning as a way to overcome discrepancies between either only practical or theoretical education. The text yields arguments for education which increases reflectivity, strengthens personal identity as the core of competence.

Key words: competences, critical competences, reflexivity, competence education

\section{Wprowadzenie}

Namysł nad nowymi aspektami konstruowania i użytkowania wiedzy oraz umiejętności, a także usytuowaniem ich $\mathrm{w}$ strukturze procesów rozwo- 
ju człowieka i społeczeństw skutkuje wielością dyskursów edukacyjnych. Konsekwencją tego jest budowanie nowej mapy zjawisk i kategorii. Jednym $\mathrm{z}$ nich jest idea kształcenia kompetencyjnego jako próba odpowiedzi na "dezadaptacyjność przeintelektualizowanego" kształcenia ${ }^{1}$. Na poziomie formalnym jest to inicjatywa stworzenia wspólnych dla obywateli Europy standardów kształcenia, lecz $\mathrm{w}$ procesie przygotowywania i implementacji zabrakło niestety naukowej dyskusji nad istotą kompetencji i sensem kompetencyjnego kształcenia. Na obecnym etapie realizacji założeń Procesu Bolońskiego wydaje się, iż nadal konieczne jest poszukiwanie odpowiedzi na wspomnianą dezadaptacyjność, ale tym razem zbyt instrumentalnego kształcenia sprawności. Kompetencje są kategorią epistemologiczną i tak w niniejszym tekście będą analizowane.

Uwzględniając szeroki i zmienny kontekst, w którym „dzieje się" edukacja, dystansujemy się od definiowania celów edukacji w wąskich, akontekstualnych kategoriach sprawności, technologii, czy specjalizacji. Argumentować za koniecznością kształcenia podmiotowego, w którym celem staje się postkonwencjonalność rozwoju jednostki, wydaje się być zadaniem oczywistym i ciągłym pedagogiki. Ujmując metaforycznie, a może tautologicznie, edukować to stwarzać szansę na pełen (możliwie postkonwencjonalny) rozwój człowieka. Charakteryzując jednak istotę tego rozwoju, zastanawiając się jakie umiejętności, sprawności, zdolności, cechy itp. świadczą o pełnym rozwoju i możliwościach adaptacyjnych, wielość potencjalnych odpowiedzi czyni jakiekolwiek jednoznaczne opisy niemożliwe. Praktyka pedagogiczna dąży do uproszczeń, a nauczyciele potrzebują wyjaśnień i wskazówek. Stąd prawdopodobnie rozdźwięk pomiędzy teorią i praktyką pedagogiczną. Nie inaczej jest, kiedy odwołujemy się do kompetencji i kształcenia kompetencyjnego.

Biurokratyzacja, przewaga interesu technicznego oraz argumentów merytokratycznych ${ }^{2}$ to kontekst, w którym edukacja staje się narzędziem do realizacji celów ideologicznych, a rozwój osoby i procesów społecznych jest uprzedmiotowiony. Upowszechnienie technologii i urządzeń informatycznych wzmacnia te zagrożenia ${ }^{3}$. Filozofia krytyczna sytuację tę nazywa desocjalizacją, czyli stanem, w którym szkoła nie pełni funkcji emancypujących, wyzwalających, a: „(...) reguły życia międzyludzkiego nabierają cech, które

\footnotetext{
${ }^{1}$ Zalecenie Parlamentu Europejskiego i Rady z 18 grudnia 2006 r. w sprawie kompetencji kluczowych w procesie uczenia się przez całe życie, http://eur-lex.europa.eu/LexUriServ/LexUri Serv.do?uri=OJ:L:2006:394:0010:0018:pl:PDF [dostęp: 11.XII.2011].

2 Z. Melosik, Uniwersytet i społeczeństwo. Dyskurs wolności, wiedzy i władzy, Kraków 2009.

${ }^{3}$ M. Czerepaniak-Walczak, Pedagogika emancypacyjna, Warszawa 2006.
} 
można określić jako >nieludzkie<. Człowiek staje się wówczas >urządzeniem peryferyjnym $<$, interfejsem działającej struktury" ${ }^{4}$. Jednocześnie, zaufanie do rozumu jako jedynej drogi do uwalniania od ograniczeń oraz rozumienia i działania $\mathrm{w}$ świecie jest zastępowane przekonaniem o wieloczynnikowym uwarunkowaniu procesów rozwoju tożsamości i krytycznej adaptacji. Dlatego, kontekst dla niniejszych rozważań o kompetencjach czerpiąc z progresywizmu, myśli krytycznej i emancypacyjnej wychodzi poza nurty pragmatyczne, traktujące edukację instrumentalnie, a także humanistyczne, upatrujące w samorealizacji człowieka sens edukacji.

\section{Dlaczego kompetencje?}

Od lat siedemdziesiątych XX wieku tworzy się listy profesjonalnych kompetencji dla różnych grup zawodowych. Zestawy te, zawierające szczegółowe opisy umiejętności, mają przyczynić się do efektywności działań $\mathrm{i}$ adaptacji $\mathrm{w}$ zmieniających się warunkach. Idea kształcenia kompetencji narodziła się jako efekt poszukiwań takich celów edukacji, których realizacja przygotowałaby człowieka do twórczej adaptacji w społeczeństwie postindustrialnym. W 1996 roku w raporcie edukacyjnym Jacques'a Delorsa ${ }^{5}$, zwracając uwagę na bezprecedensowe warunki obiegu wiedzy, autorzy odnosili się do dwóch zasadniczych nakazów dla edukacji: przekazywania wiedzy i umiejętności oraz "dostarczenia mapy złożonego i wiecznie niespokojnego świata i busoli umożliwiającej po nim żeglugę" 6 . W takim kontekście rozpowszechniono kategorię kompetencji, rozumianych jako wiedza, postawy i umiejętności praktyczne umożliwiające orientację $\mathrm{w}$ świecie i korzystanie $\mathrm{z}$ osiągnięć technologicznych. Jednak w opisywanym raporcie wątpliwości może budzić pewien instrumentalizm. W "przekazywaniu”, "dostarczaniu” wiedzy i umiejętności tkwi niebezpieczeństwo kolonizowania umysłu: kształtowania nawyków, schematów, które ograniczają samodzielność intelektualną. Zamiast wypracowanej mapy działań, specjalistycznych kompetencji, „wewnętrzną busolą" człowieka, punktem odniesienia jest tożsamość ${ }^{7}$ i może być kompetencja znacznie bliższa refleksyjności i mądrości aniżeli wskazuje lista tzw. kompetencji kluczowych ${ }^{8}$.

\footnotetext{
4 Tamże, s. 125.

${ }^{5}$ J. Delors, Edukacja: jest w niej ukryty skarb, Warszawa 1998.

6 Tamże, s. 85.

7 A. Gałdowa (red.), Tożsamość człowieka, Kraków 2000.

${ }^{8}$ Zalecenie Parlamentu Europejskiego i Rady z 18 grudnia 2006 r.
} 
Pojęcie kompetencji funkcjonuje w języku potocznym, psychologii, socjologii i naukach ekonomicznych. Od lat dziewięćdziesiątych XX wieku przyjęło się również w naukach o wychowaniu9. Potocznie utożsamiamy to pojęcie z uprawnieniami, czy też możliwościami sprawnego działania w sferze zawodowej. Popularność sam termin zyskał dzięki lingwistyce i koncepcji kompetencji komunikacyjnej Noama Chomskiego ${ }^{10}$. Kompetencje utożsamiamy z szerokim repertuarem postaw, cech, umiejętności, zdolności, motywacji czyniących działanie sprawnym $\mathrm{w}$ danym obszarze ${ }^{11}$. Mimo precyzyjnych wyliczeń, jakie kompetencje są niezbędne, nadal pozostaje dylematem, jakie są „najważniejsze”, bez których człowiek będzie tylko zbiorem luźnych dyspozycji, kapitałem, w który zainteresowane instytucje inwestują. Mimo deklaracji dysydentów oświaty, iż kształcenie kompetencyjne zlikwiduje rozdźwięk pomiędzy oczekiwaniami indywidualnymi a społecznymi (również pracodawców), nadal pozostaje dyskusyjne, czy wyliczane umiejętności, które powinny posiąść jednostki, służą tylko podtrzymaniu wolnorynkowego status quo czy refleksyjnej adaptacji?

Za sprawą wieloznaczności pojęcie kompetencji jest powszechnie używane i stało się eufemizmem, któremu nadajemy znaczenie zależnie od kontekstu. Maria Czerepaniak-Walczak zauważa, że kompetencje jako słowo klucz nabrało cech słowa - wytrycha, bowiem stosuje się je wszędzie tam, gdzie brakuje określeń dla właściwości człowieka12. Kompetencje są pojęciem kojarzonym $\mathrm{z}$ orientacją instrumentalną $\mathrm{w}$ edukacji, przygotowaniem specjalistycznym do pełnienia ról zawodowych, czy też sprawnością techniczną. Obecnie, między innymi w efekcie wprowadzania europejskich standardów kształcenia, pojęcie to jako swoisty konstrukt teoretyczny staje się synonimem wszelkich możliwości człowieka, które warunkują sprawność jego działania.

W zarządzaniu zasobami ludzkimi pojawiają się definicje ${ }^{13}$, zaczerpnięte z teorii motywacji, mówiące, że kompetencje to konglomerat wiedzy, umiejętności i postaw wyrażających gotowość do działania ${ }^{14}$. 1998.

9 Por. D. Gołębniak, Zmiany edukacji nauczycieli: wiedza - biegłość - refleksyjność, Toruń

${ }^{10}$ N. Chomsky, Aspects of the theory of syntax, Cambridge 1965.

${ }^{11}$ J.M. Madalińska-Michalak, R. Góralska, Kompetencje emocjonalne nauczyciela, Warszawa 2012, s. 68-70.

${ }_{12}$ M. Czerepaniak-Walczak, Pedagogika emancypacyjna, s. 128.

${ }_{13}$ M. Kossowska, I. Sołtysińska, Szkolenia pracowników a rozwój organizacji, Kraków 2002.

${ }_{14}$ T. Tomaszewski, Podstawowe formy organizacji i regulacji zachowania, [w:] Psychologia, red. T. Tomaszewski, Warszawa 1978, s. 491. 
Operacjonalizując złożone pojęcie, redukujemy przestrzeń pomiędzy elementami składowymi, jednak dzięki temu uzyskujemy zestaw dyspozycji, które możemy rozpoznawać i oceniać (bardziej lub mniej trafnie) przez badania empiryczne zachowań jednostki i optymistycznie zakładając edukować. Należy przyjąć, iż pojęcie kompetencji jest konstruktem teoretycznym, który w uproszczony sposób charakteryzuje dyspozycje jednostki umożliwiające poznawanie, rozumienie, działanie i interakcje: dyspozycje poznawcze, moralne, interakcyjne, ale również działania praktyczne ${ }^{15}$. Chcąc uniknąć uproszczeń, które zarówno w teorii jak i praktyce edukacyjnej dzieją się, należałoby zwrócić uwagę na przestrzeń pomiędzy elementami tej struktury, którą „wypełnia” tożsamość jednostki, a także zróżnicowany status „komponentów" ze względu na możliwości ich nabywania i związek z podmiotowymi dyspozycjami. Skoro kompetencje są dyspozycją osobową, rozwijaną $\mathrm{w}$ działaniu, to kategoria doświadczenia staje się centralnym ogniwem w procesie kształtowania i poszerzania kompetencji. Otwartość kompetencji, a także złożoność pozioma (różnorodność postaw, zachowań, umiejętności, zdolności itp.) i pionowa (hierarchia) ${ }^{16}$ powodują, iż kształcenie kompetencji $\mathrm{w}$ warunkach oderwanych od tych, w których będą wykorzystywane staje się wręcz niemożliwe.

\section{Orientacje w (re)konstrukcji kompetencji i kształcenia kompetencyjnego}

Polisemia pojęcia kompetencje umożliwia jego interpretowanie, nawet na poziomie metateoretycznym, w zależności od przyjmowanych założeń epistemologicznych, ontologicznych, czy metodologicznych. Poniższe interpretacje dzieją się jednak na styku teorii i praktyki: ideologii, ideologii wychowania, myśli psychologicznej, pedagogicznej i socjologicznej. Pozycja człowieka na kontinuum przedmiot - podmiot, sprawność - mądrość, odtwórczość - twórczość to wybrane obszary dla interpretacji kształcenia kompetencyjnego w kontekście orientacji technologicznej, humanistycznej i krytycznej.

Orientacje pokazują różne przestrzenie nabywania, rozwijania i uobecnienia kompetencji w zachowaniu i postawach człowieka. Każda z nich jest osadzona $\mathrm{w}$ innym paradygmacie nauki, odwołuje się do innych założeń

${ }^{15}$ H. Kwiatkowska, Pedeutologia, Warszawa 2008, s. 34.

${ }^{16}$ R. Kwaśnica, Wprowadzenie do myślenia o wspomaganiu nauczyciela w rozwoju, Studia Pedagogiczne, 1995, 61. 
ontologicznych, epistemologicznych i metodologicznych ${ }^{17}$. Odpowiada też na inny kontekst ideologiczno-społeczny.

W paradygmacie technologicznym kompetencje rozumiemy dyspozycjonalnie, jako zestaw umiejętności, sprawności, zachowań i wiedzy praktycznej. $\mathrm{W}$ takim sensie kształcenie kompetencyjne jest kształceniem instrumentalnym. Kompetencje nabywane są przez uczenie się społeczne, poznawanie praktyki i strukturę wzmocnień ${ }^{18}$.

Technologiczne podejście do uczenia się i kompetencji odnajduje swoje uzasadnienie $\mathrm{w}$ psychologii uczenia się behawioralnego i paradygmacie pozytywistycznym. Jeśli odwołać się do tradycji zaczerpniętych od Burrhusa Frederika Skinnera i Edwarda Thorndika, to uczenie się kompetencji byłoby procesem instrumentalnym, behawioralnym, odbywającym się pod wpływem bodźców zewnętrznych. Pozytywistyczne ujmowanie wiedzy i poznania oraz traktowanie ich $\mathrm{w}$ kategoriach instrumentalnych jako narzędzia kontrolowania oraz zmieniania środowiska oznacza, że edukacja ma za zadanie przygotować do inteligentnego przystosowania się do zewnętrznego świata ${ }^{19}$. Dlatego kompetencje rozumiane technologicznie odarte są z kategorii podmiotowości, autonomii i systemu wartości, a ograniczone do wiedzy, wypreparowanych praktyk i wybranych cech osobowości. Tu wiedza nie uobecnia się $\mathrm{w}$ procesie jej konstruowania, ale nabywana jest przez obserwację tzw. „dobrej praktyki” i ma wymiar praktyczny. Fachowość, profesjonalizm, czy sprawność charakteryzują przygotowanie do zawodu, którego raczej nie wiąże się z rozwojem człowieka jako całości. Kompetencyjność instrumentalna uzewnętrznia się $w$ działaniach skutecznych przez operowanie sprawdzonymi technikami i schematami działań. Zdobywanie wiedzy, jako jednego z elementów konstytuujących kompetencje, jest rozumiane jako transmisja wiedzy, tradycji, norm, wartości, zgeneralizowanych przez przeszłe pokolenia. Natomiast, wiedza i jej wartość wyznacza możliwość przewidywania w celu skutecznego działania ${ }^{20}$.

Instrumentalizm $\mathrm{w}$ traktowaniu działań człowieka i procesu przygotowania do życia jest wyrazem tzw. racjonalności kognitywno-instrumentalnej21. Mówiąc o tej racjonalności Garry Evert zwraca uwagę iż: „ostatecznym rezultatem jest tu redukcja kwestii moralnych, estetycznych, edukacyjnych

17 Por. H. Kwiatkowska, Nowa orientacja w ksztatceniu nauczycieli, Warszawa 1988, s. 12.

18 J.M. Madalińska-Michalak, R. Góralska, Kompetencje emocjonalne nauczyciela, s. 69.

19 J. Habermas, Teoria dziatania komunikacyjnego. Racjonalność dziatania a racjonalność społeczna, t. 1, przekł. A.M. Kaniowski, Warszawa 1999, s. 33.

20 Por. H. Kwiatkowska, Nowa orientacja w kształceniu nauczycieli, s. 34-50.

${ }^{21}$ Racjonalność ta wg H.A. Giroux to techniczna, R. Kwaśnica nadaje jej nazwę adaptacyjnej. 
i politycznych do problemów technicznych: pytania typu dlaczego i co są redukowane do pytań typu jak"22. Kompetencje w takiej racjonalności są typu "instant": kondensowane do typowo technicznych, praktycznych, nie wymagających refleksyjności tylko raczej elastyczności, a gwarantujące "szybki" efekt, natychmiastową reakcję. Kształcenie jest wąskie, specjalistyczne, jest środkiem adaptacji zawodowej i społecznej, a rozwój jest procesem sterowanym $\mathrm{z}$ zewnątrz, na zasadzie transmisji wiedzy, wartości i norm.

Zewnętrzność, przedmiotowość to kategorie, przez które aktywność człowieka zarówno w edukacji jak i życiu sprowadzana jest do odbioru komunikatów i dostosowania się do oczekiwań otoczenia. Kształcenie kompetencji instrumentalnych jest procesem powtarzalnym i przygotowującym do działań stereotypowych. Cele definiowane są w terminach ustalonej wiedzy i umiejętności wyznaczanych przez standardy poprawności kulturowej23. Przykładem takiego redukowania kompetencji są listy praktycznych kompetencji nauczycielskich: merytoryczne, diagnostyczne, organizacyjne, komunikacyjne, badawcze, informatyczne... ${ }^{24}$. Kompetencje te precyzyjnie charakteryzują wiedzę, umiejętności i zachowania, które powinny być prezentowane przez nauczycieli i przynajmniej teoretycznie gwarantują skuteczność działań.

Akceptując zależność społeczeństwa od nieosobowych kodów informacyjnych, techniczno-racjonalne rozumienie kompetencji nasycone jest biernością i ujednoliceniem standardów kształcenia tak, jakby celem była „wspólna indywidualność” 25. Mimo że z założenia kompetencje techniczne mają prowadzić do adaptacji do ról zawodowych i społecznych, to obserwujemy dezadaptacyjność takiego wymiaru kształcenia, które nie odpowiada na zapotrzebowanie ani indywidualne, ani społeczne $\mathrm{w}$ płynnej nowoczesności. Refleksyjność, samodzielność intelektualna i egzystencjalna nie mogą być przedmiotem wyboru gdyż: „Chronicznym atrybutem ponowoczesnego stylu życia wydaje się być niespójność, niekonsekwencja postępowania, fragmentaryczność i epizodyczność rozmaitych sfer aktywności jednostek"26.

${ }^{22}$ G. Evert, Habermas i edukacja, [w:] Nieobecne dyskursy, cz. III, red. Z. Kwieciński, Torun 1993, s. 123.

${ }^{23}$ Por. L. Kohlberg, R. Mayer, Rozwój jako cel wychowania, [w:] Alternatywy myślenia o/w edukacji, red. Z. Kwieciński, Warszawa 2000.

24 Por. H. Kwiatkowska, Nowa orientacja w ksztatceniu nauczycieli, s. 17.

25 Por. L. Kohlberg, R. Mayer, Rozwój jako cel wychowania, s. 53.

${ }^{26}$ Z. Bauman, Ponowoczesne wzory osobowe, Studia Socjologiczne, 1993, 2, s. 31. 
Rekonstruując myślenie o kompetencjach w kontekście założeń psychologii humanistycznej (orientacja humanistyczna), można dostrzec zainteresowanie osobowym wymiarem kompetencji. Koncentracja na człowieku, a przede wszystkim procesie "stawania się" spowodowała, że punkt ciężkości został przesunięty z "efektów” oddziaływań edukacyjnych (tu: kompetencji) na sam proces rozwoju i uczenia się. Janusz Kozielecki opisując koncepcje psychologiczne człowieka, podkreśla niepowtarzalny charakter jego osobowości, który nie daje się sprowadzić do zestawu oderwanych od siebie komponentów: postaw, potrzeb, myśli, umiejętności, zdolności ${ }^{27}$. Ta „,jednorazowość" osobowości sprawia, że edukacja ma charakter osobisty i toczy się w kierunku swoistym dla jednostki. Tym samym kompetencje byłyby kompetencjami tylko osobistymi, innymi dla każdej jednostki, realizowanymi w procesie samoaktualizacji.

Idąc tym tropem, nabywanie i rozwijanie kompetencji jest także procesem jednostkowym, pochodzącym $\mathrm{z}$ wnętrza i realizującym się $\mathrm{w}$ relacjach z innymi. Kompetencje aktualizują się w kontekście osobowości człowieka, a ich rozwój jest zintegrowany z rozwojem osobistym ${ }^{28}$. Odczytując dalej, edukacja jest procesem nie tyle nabywania kompetencji, co ich odkrywania, tworzenia i poszerzania, a jednostka nie rozwinie kompetencji jeśli nie ma wewnętrznej motywacji i nie uczestniczy aktywnie w procesie uczenia.

W 1959 roku Robert W. White badający motywację człowieka, zaproponował koncepcję osobistej kompetencji jako czynnika w znaczący sposób wzmacniającego efektywność działań i funkcjonowania człowieka w środowisku $^{29}$. Inaczej niż motywy biologiczne, motywacja kompetencji (competence motives) nigdy nie jest ostatecznie spełniona i tak rozumiana kompetencja prowadzi do rozwoju osobistego. Kompetencja osobista, w świetle założeń R.W. White'a, to zdolność angażowania się w transakcje w zmiennym, czasem niekorzystnym środowisku społeczno-fizycznym ${ }^{30}$. Jednocześnie, właśnie przez kontakt ze środowiskiem (szczególnie językowym i społecznym) dyspozycje te rozwijają się. Pragmatyczność kompetencji, ich wymiar instrumentalny wyrażałby się w powtarzalnych czynnościach, które do pewnego stopnia są zautomatyzowane. Natomiast kompetencja jako dyspozycja do działania może rozwijać się, kiedy od jednostek oczekuje się twórczej adaptacji. Motywacja kompetencji byłaby bliska humanistycznej koncepcji

\footnotetext{
27 J. Kozielecki, Koncepcje psychologiczne człowieka, Warszawa 1980, s. 258.

28 Por. H. Kwiatkowska, Pedeutologia, Warszawa 2008.

${ }^{29}$ R. White, Motivation reconsidered - the concept of competence, Psychological Review, 1959,

30 Tamże.
} 66(5), s. 297-333. 
Roberta Maslowa dotyczącej samorealizacji człowieka jako jego najwyższej potrzeby. Również tu samorealizacja jest procesem nigdy nie zakończonym, zawsze otwartym ${ }^{31}$.

Przyjmując fundamentalne założenia nurtów humanistycznych, mówiące, że człowiek jest autonomiczną całością, a poznanie ma charakter podmiotowy, realizujący się $\mathrm{w}$ relacji komunikacyjnej ze światem, to należy przyjąć, że kompetencyjne działanie „domyka się" w i przez osobowość człowieka. Rozwój kompetencji w rozumieniu humanistycznym jest ściśle powiązany z rozwojem osobowym i odbywa się tylko przez aktywny udział podmiotu. Jeśli, jak twierdził C. Rogers, to człowiek jest procesem („person is a process"), stawanie się człowiekiem nie może być drugoplanowe wobec uczenia się taktyk i strategii życia oraz pracy, jak często są interpretowane kompetencje $^{32}$. Tym samym, każdy uczeń, każdy człowiek z natury, ma prawo docierać do innego, właściwego tylko dla siebie charakteru kompetencji, które są częściowo uwarunkowane predyspozycjami, ale w dużej mierze podatne na wpływy zewnętrzne (edukacyjne, społeczne).

Ponowoczesna kondycja widoczna między innymi we fragmentaryczności rzeczywistości, braku przejrzystych punktów odniesienia (autorytetów), czy Baudrillardowskim niepowstrzymanym rozroście rzeczy czynią tożsamość zadaniem do wykonania:

Najlepiej wiedzie się osobnikom, których swobody ruchu nie krępuje precyzyjna specjalizacja, którzy nie mają w zwyczaju koncentrowania uwagi zbyt długo na jednym przedmiocie (...) zachowują dystans i wstrzemięźliwość emocjonalną wobec tego czym się w każdym momencie zajmują

mówi Bauman opisując ponowoczesne wzory osobowe ${ }^{33}$. Rozumiejąc kompetencję krytycznie jako kompetencję do działania, byłaby ona poznawczym, emocjonalnym i działaniowym wyrazem stylu syntezy doświadczenia konstytuującego tożsamość w ujęciu Erika Eriksona ${ }^{34}$. Jeśli kompetencja rozwija się i aktualizuje na styku własnych predyspozycji oraz doświadczeń, to złożoność ontologiczna „otoczenia”, w którym działamy implikuje złożoność struktury kompetencji i elementów je konstytuujących. Komponent poznawczy to postawa, gotowość do rewidowania wiedzy, emocjonalny jest poszukiwaniem uzasadnień emocjonalno-moralnych działań i obserwowal-

\footnotetext{
${ }^{31}$ A. Maslow, Motywacja i osobowość, Warszawa 2010.

32 B. Thorne, C. Rogers, Twórcy psychoterapii, Gdańsk 2006.

33 Z. Bauman, Ponowoczesne wzory osobowe, s. 24-25.

${ }^{34}$ L. Witkowski, Rozwój i tożsamość w cyklu życia. Studium koncepcji E.H. Eriksona, Toruń
} 2000, s. 141-145. 
ny, działaniowy wyraża refleksyjne projektowanie działań i gotowość tolerowania zmienności oraz niejednoznaczności.

„Bycie w świecie może odbywać się na różne sposoby” - możemy być podmiotem bądź pełnić zaadaptowaną rolę 35 . Zgodnie z tym przekonaniem, edukacja może służyć adaptacji do roli bądź adaptacji samej roli. Paulo Freire zwracał wagę na niebezpieczeństwo pełnienia przez szkołę tylko funkcji adaptacyjnych $\mathrm{w}$ sensie zarówno społecznym, jak i intelektualnym, gdyż szkoła, która nie uczy refleksyjnej krytyki rzeczywistości, zapamiętywania, a nie rozumienia nie jest ogniwem edukacyjnym ${ }^{36}$. Człowiek jako podmiot ma prawo do wyrażania i realizacji swoich naturalnych potrzeb (ujęcie romantyczne), a także emancypacji społecznej (ujęcie krytyczno-emancypacyjne) i kulturowej ekspresji. Maria Czerepaniak-Walczak wskazuje na swoisty paradoks edukacji, której celem powinno być przygotowanie człowieka do dorosłości, rozumianej jako samodzielne i odpowiedzialne życie. Okazuje się jednak, że korzystanie z oferty edukacyjnej oznacza raczej adaptację roli, „mówienie cytatami" i często jest reprodukcją statusu społecznego rodziców ${ }^{37}$. Czyli, kończy się w najlepszym przypadku osiągnięciem kompetencji adaptacyjnych, a osobie nadawany jest status dorosłego. Lech Witkowski, odwołując się do koncepcji rozwoju Lawrenca Kohlberga, mówi o triadzie rozwojowej przedkonwencja-konwencja-postkonwencja jako przechodzeniu od „wspólnoty interesów”, przez „wspólnotę zadań”, do realizowanej w płaszczyźnie dialogowej „wspólnoty jako zadania”, kiedy autonomia w kreowaniu siebie i współuczestniczenie w kreowaniu społeczności jest sposobem istnienia $\mathrm{w}$ świecie ${ }^{38}$. Przekroczenie ograniczeń adaptacyjnych $\mathrm{w}$ edukacji zgodnie $\mathrm{z}$ ideologią liberalną byłoby możliwe dzięki stworzeniu projektu, w którym treści, metody, tempo osiągania "wzorów" jest dostosowane do indywidualnych możliwości jednostki. Jak jednak zrealizować ideę samorealizacji i przygotowania do pełnej autoekspresji w szkole, która jak pisze Maria Dudzikowa jest tylko mitem miejsca wszechstronnego rozwoju ${ }^{39}$ ?

Z perspektywy krytycznej przekroczenie potrzeby bezwzględnego dostosowania się i heteronomii norm moralnych osiągane na etapie postkonwencji jest wyrazem osobistego ustosunkowania się, odnalezienia w świecie i stanem gotowości do redefinicji własnej tożsamości w obliczu złożoności

${ }^{35}$ M. Czerepaniak-Walczak, Pedagogika emancypacyjna, s. 116.

36 P. Freire, Pedagogy of freedom. Ethics, Democracy, and Civic Courage, Lanham 2001.

${ }^{37}$ M. Czerepaniak-Walczak, Pedagogika emancypacyjna, s. 117.

${ }^{38}$ L. Witkowski, Tożsamość i zmiana. Epistemologia i rozwojowe profile edukacji, Wrocław 2010, s. $166-167$.

${ }^{39}$ M. Dudzikowa, Mit o szkole jako miejscu "wszechstronnego rozwoju” ucznia, Kraków 2004, s. $23-25$. 
świata - przejawem kompetencji do działania ${ }^{40}$. Tak rozumiane kompetencje mają wymiar osobowy i społeczny. Już Sergiusz Hessen dostrzegał w wartościach kulturowych czynnik przejścia na wyższe poziomy rozwoju osobowości, a w autonomii jednostek - motyw przejścia społeczeństwa na etap postkonwencjonalny rozwoju ${ }^{41}$. Jurgen Habermas eksponując ten związek pisze:

Proces uczenia się społeczeństw jest zależny od kompetencji należących do jednostek. Te z kolei uzyskują swoje kompetencje nie jako odosobnione monady, ale wrastając w symboliczne struktury świata w jakich żyjemy ${ }^{42}$.

Krytyka edukacji, zwłaszcza w jej wymiarze formacyjnym i ideologicznym, dokonywana przez nurty krytyczne pedagogiki i socjologii, eksponuje konieczność społecznego oporu wobec wszelkich form zniewolenia i narzuconych ograniczeń statusu społecznego. Henry Giroux przekonuje, że szkoła może przyczynić się do kształtowania postaw emancypacyjnych, ale wzmacniając kompetencje krytyczne i aktywnego działania społecznego. Szkoła, jeśli zostanie uznana za "sferę publiczną" życia uczniów ${ }^{43}$, to doświadczenia edukacyjne i obcowanie z nauczycielami „zmusi” w niej do aktywności intelektualnej, emocjonalnej i społecznej. Myśl krytyczna w praktyce miałaby być realizowana przez dawanie "głosu" po to, aby artykułować potrzeby, oczekiwania i wyzwalać się z ograniczeń, np. pochodzenia, języka, wyznania ${ }^{44}$. Nauczyciel mógłby być inicjatorem takiego dialogu, a dzięki swoim kompetencjom i przekonaniom stwarzać przestrzeń do aktywności społecznej.

W zracjonalizowanym świecie potrzebę uzyskania porozumienia $\mathrm{w}$ coraz mniejszym stopniu zaspokaja odporny na krytykę zasób tych interpretacji, które uwiarygodnia tradycja; na poziomie w pełni zdecentralizowanego rozumienia świata potrzebę konsensu musi coraz częściej zaspokajać ryzykowna, albowiem racjonalnie motywowana zgoda - uzyskiwana czy to bezpośrednio dzięki interpretacjom dokonywanym przez samych uczestników, czy też dzięki profesjonalnej wiedzy ekspertów, która jest wtórnie przyswajana jako własna ${ }^{45}$.

40 Por. L. Kohlberg, R. Hersh, Moral development - a review of theory, Theory into Practice, 1977, 16(2), s. 53-59.

41 S. Hessen, Podstawy pedagogiki, Warszawa 1997.

42 J. Habermas, Teoria i praktyka: wybór pism, Warszawa 1983, s. 504.

${ }^{43}$ T. Szkudlarek, Pedagogika krytyczna, [w:] Wyzwania pedagogiki krytycznej i antypedagogiki, red. T. Szkudlarek, B. Śliwerski, Kraków 2000, s. 30.

44 Tamże, s. 34.

45 J. Habermas, Teoria dziatania komunikacyjnego, t. 1, Warszawa 1999, s. 557. 
Tak Jürgen Habermas wskazuje na nowe źródła i sposoby korzystania $\mathrm{z}$ wiedzy w społeczeństwie, które nie jest $\mathrm{w}$ stanie racjonalizować jej na drodze empiryczno-analitycznej i uzasadnia przejście z racjonalności kognitywno-instrumentalnej do komunikacyjnej ${ }^{46}$.

W racjonalizowaniu komunikacyjnym odchodzi się od zgody narzuconej z góry, arbitralnie przez tradycję, do działania ukierunkowanego na porozumienie. Komunikując się, osiągamy porozumienie i konsensus, a podmioty są w intersubiektywnym związku ${ }^{47}$. Jürgen Habermas w swojej teorii krytycznej dopuszcza uniwersalność wartości w przypadku wartości fundamentalnych. Dążenie do zrozumienia i uzgadniania znaczeń generuje interesy praktyczne, mogą to być interesy emancypacyjne, kiedy wartości, roszczenia "ważnościowe”: prawdziwość, słuszność, szczerość i zrozumiałość są spełnione ${ }^{48}$. Komunikacyjność to również cecha ontyczna podmiotów, która zakłada, że zarówno środki jak i cele działania człowieka mają charakter komunikacyjny ${ }^{49}$.

Habermasowska wielopostaciowość racjonalności ludzkiej oraz złożoność rzeczywistości społecznej wymaga komplementarnych podejść do kształcenia kompetencji. Odpowiedzią na technologizację społeczeństwa i relatywizację podstawowych kategorii może być holistyczne interpretowanie kompetencji, jako wyraz krytycznego ustosunkowania się do otoczenia i własnego w nim miejsca. Stąd pojawia się propozycja rozumienia kompetencji w perspektywie krytycznej, przedstawionej w dalszej części tekstu.

David Carr dokonuje rozróżnienia pomiędzy wspomnianym rozumieniem dyspozycjonalnym kompetencji, kiedy mówimy o listach, zestawach kompetencji (liczba mnoga), a kompetencją (liczba pojedyncza) jako holistyczną zdolnością dokonywania osądu ${ }^{50}$. Kompetencja i kompetencje w retoryce tego autora nie są częścią tego samego kontinuum: przejście od kompetencji jako zestawu dyspozycji do kompetencji jako czynnika refleksyjnego nie jest oczywiste. Kompetencje byłby to zbór umiejętności, sprawności przedstawianych $\mathrm{w}$ postaci list kompetencji, np. profesjonalnych (przykład zestawy kompetencji nauczycielskich). Kompetencja byłaby natomiast wymiarem osobowym, uwewnętrznionym - holistyczną zdolnością dokonywania osądu ${ }^{51}$. Rozwój osobistej kompetencji musi więc następować

46 Tamże, s. 48.

47 Tamże, s. 134-139.

48 Tamże, s. 33.

49 Tamże, s. 34.

50 D. Carr, Questions of competence, British Journal of Educational Studies, 1995, 41(3), s. 262-263.

51 Tamże, s. 262-263. 
jednocześnie z nabywaniem umiejętności pragmatycznych - kompetencji. Byłyby to procesy dziejące się równolegle, które wymagałyby wzrastającej stymulacji refleksyjnego myślenia wraz z nabywaniem kompetencji adaptacyjnych. Nieodłącznym składnikiem zaistnienia tak rozumianej kompetencyjności jest refleksyjność, samoświadomość, odniesienia moralne i motywacja. Kompetencja byłaby częścią „bazy epistemologicznej” do interpretacji zakresów tożsamości, „kluczem głębokiego osadzenia tożsamości”52. Kompetencja nie podlegałaby więc treningowi, nie byłaby efektem kształcenia, a raczej trwałą dyspozycją jednostki do działania, wyrażającą jej skłonności, motywację i typ zaangażowania, będący argumentem za realizacją określonej koncepcji siebie w świecie ${ }^{53}$.

Odwołując się do epistemologii Lawrence'a Kohlberga, powiedzielibyśmy, że kompetencję osiągamy dopiero na etapie postkonwencjonalnym rozwoju. Dla wcześniejszych etapów, zwłaszcza przedkonwencjonalnego, charakterystyczne jest działanie zgodnie z konwencją ról zawodowych i społecznych, które wymaga kompetencji w rozumieniu instrumentalnym. Etap konwencjonalny umownie oznaczałby stopniowe przechodzenie od działań odtwórczych, schematycznych o dużym stopniu powtarzalności, do działań samodzielnych, twórczych ${ }^{54}$. Co więcej, kompetencje adaptacyjne, charakterystyczne dla etapów wcześniejszych, nie gwarantują osiągnięcia szeroko rozumianej kompetencji (profesjonalizmu, mistrzostwa, refleksyjności zawodowej) na etapie postkonwencjonalnym ${ }^{55}$.

(...) profesjonalnej kompetencji (competence) nie da się redukować do kompetencji (competences) w dyspozycjonalnym sensie, ponieważ jej przełomowym komponentem jest artykulacja i demonstrowanie moralnych wartości danej profesji56.

Korzystając z tropów w koncepcji Kazimierza Dąbrowskiego - aby przejść na wyższe fazy rozwoju kompetencji - musi dojść do dezintegracji pozytywnej - rozpadu struktur rozwojowo niższych na korzyść tych bardziej złożonych ${ }^{57}$. Rozwój kompetencji polegałby na wyjściu od kompetencji adaptacyjnych i stopniowym dochodzeniu do krytycznych i emancypacyjnych. To przechodzenie można utożsamić z kryzysami - rozwojowym -

\footnotetext{
52 L. Witkowski, Tożsamość i zmiana, s. 143.

53 Tamże, s. 146.

${ }^{54}$ L. Kohlberg, R. Hersh, Moral development, s. 53-59.

55 Tamże, s. 55.

${ }^{56}$ D. Carr, Questions of competence, s. 264.

${ }^{57}$ K. Dąbrowski, Dezintegracja pozytywna, Warszawa 1979.
} 
w których powinno dojść do rozwikłania konfliktu pomiędzy adaptacją a twórczą dezadaptacją $\varepsilon^{58}$.

W orientacji krytycznej kompetencje należy rozumieć dynamicznie. Są one raczej kognitywną strukturą, która podlega reorganizacji, aniżeli zestawem umiejętności, wiedzy, czy postaw. Rozwój kompetencji może być utożsamiany z przechodzeniem (progress) na wyższe stadia rozwoju, umożliwiające poszerzenie kompetencji zarówno poznawczych, jak i osobowych. Stadia te, nawiązując również do Jana Piageta, są względnie stałe, jakościowo różne i hierarchicznie ustrukturyzowane; niższe stadia są podstawą do rozwoju kolejnych ${ }^{59}$. R. Kwaśnica interpretując etapy rozwoju moralnego, wskazane przez L. Kohlberga, zauważa, że kompetencje nie są nigdy skończone, a rozwój polega na ich przekraczaniu ${ }^{60}$.

Progresywizm podkreśla znaczenie krytycznego myślenia i konstruowania wiedzy jako immanentnych komponentów kompetencji, które z założenia zależą przecież od doświadczenia. Pogląd ten, wywiedziony od J. Locke'a, wskazuje na znaczenie kształcenia refleksyjności i pobudzania umysłu oraz rolę doświadczenia $\mathrm{w}$ poznaniu ${ }^{61}$, jednakże to orientacja instrumentalna zdominowała edukację jeszcze w II połowie XX wieku.

Progresywiści podkreślają interakcjonizm w procesie rozwoju, w którym znaczącą rolę odgrywa doświadczenie i konflikt poznawczy. Doświadczenie rozumiane jako proces weryfikowania, przedefiniowywania postaw, myśli, zachowań, a także konflikt poznawczy ${ }^{62}$ - jako problemowość sytuacji edukacyjnej są warunkami niezbędnymi dla rozwoju kompetencji. Autentyczne doświadczanie doprowadza do konfrontacji kompetencji: jeśli ich implikacje zostaną doświadczalnie wyczerpane poprzez dialogiczną interakcję z otoczeniem może zachodzić progres, czyli ich rozwój63. Więc, tak jak wskazuje J. Dewey, tylko te doświadczenia mają wartość wychowawczą, które zapisują się twórczo w kolejnych doświadczeniach ${ }^{64}$. Natomiast, aktywność podmiotu stymulowana poprzez ciekawość i wątpliwości doprowadza do reorganizacji myślenia, przeżywania emocji oraz moralności, czyli zmiany postaw i w efekcie kompetencji.

58 M. Czerepaniak-Walczak, Pedagogika emancypacyjna, s. 130-131.

${ }^{59}$ D. Garz, Lawrence Kohlberg - Introduction, Leverkusen 2009, s. 34.

${ }^{60} \mathrm{R}$. Kwaśnica, Wprowadzenie do myślenia. O wspomaganiu nauczyciela w rozwoju, Studia Pedagogiczne, 1995, 61, s. 9-41.

61 S.I. Możdżeń, Historia wychowania, t. I, s. 359-362.

${ }^{62}$ J. Dewey, Demokracja $i$ wychowanie, Wrocław-Warszawa-Kraków-Gdańsk 1972, s. $192-$ 199.

${ }^{63}$ L. Kohlberg, R. Mayer, Rozwój jako cel wychowania, s. 30-31.

${ }^{64}$ J. Dewey, Demokracja i wychowanie, s. 199. 
Rozwój kompetencji jest więc przekształceniem struktur poprzez doświadczanie i interakcje, a nie tylko ćwiczeniem umiejętności (orientacja technologiczna) czy dążeniem do samorealizacji (orientacja humanistyczna). Celem kształcenia kompetencji jest funkcjonalny rozwój struktur poznawczych, które są źródłem interpretowania rzeczywistości, nadawania jej znaczenia i ustosunkowania się wobec niej. W tym kontekście kompetencje byłyby strukturą złożoną, hierarchiczną, rozwijającą się w kierunku refleksyjności, samodzielności intelektualnej i moralnej. Wydaje się, że takie rozumienie nadaje kompetencjom sens mądrości: „Wiedza jest informacją umieszczoną $\mathrm{w}$ kontekście, a mądrość jest wiedzą umieszczoną $\mathrm{w}$ systemie wartości w celu właściwego użycia danych, informacji i wiedzy"65.

Największą niezależność poznawczą i autonomię moralną osiągamy na etapie postkonwencjonalnym. Prawdopodobnie właśnie dopiero człowiek na tym etapie jest $\mathrm{w}$ pełni samodzielnym podmiotem, twórczym i refleksyjnym. Wtedy też ujawnia się indywidualny sposób bycia w określonej roli (społecznej, zawodowej), tym samym stanowiąc rdzeń kompetencji.

W ujęciu krytycznym uobecniony jest postulat nasycania wiedzą czynności praktycznych. Bynajmniej nie oznacza to przyswajania wiedzy teoretycznej, ani uczenia poprzez kumulowanie doświadczeń (wiedzy, umiejętności, wartości), ale podejście metodologiczne i badawcze $\mathrm{w}$ procedurze poznania. L. Kohlberg nawiązując do J. Deweya i J. Piageta wskazuje, że dojrzała myśl jest efektem reorganizacji struktur poznawczych $\mathrm{w}$ interakcji ze środowiskiem: „Te reorganizacje odzwierciedlają jakościowe poziomy myśli, poziomy zwiększonej epistemologicznej odpowiedzialności"66. Nabywanie kompetencji $\mathrm{w}$ takim rozumieniu uzasadniają procesualno-poznawcze wzory uczenia się, konstruktywizm poznawczy oraz modele interakcyjne.

Konkludując, wyznacznikami orientacji krytycznej w rozumieniu kompetencji i kształcenia kompetencyjnego jest konstruowanie i rekonstruowanie struktur poznawczych, osobowościowych i działaniowych, które tworzą (konstytuują i rozwijają) kompetencje. Jednocześnie kompetencje są operacjonalizowane jako struktura złożona $\mathrm{z}$ kompetencji umożliwiających adaptację, krytyczną postawę i ostatecznie emancypację ${ }^{67}$. W kompetencjach adaptacyjnych, umożliwiających orientację $\mathrm{w}$ rzeczywistości, kategorią poznania jest informacja. Kompetencje krytyczne pozwalają na zrozumienie znaczenia i interpretację rzeczywistości w systemie wartości i wiedzy. Na-

\footnotetext{
65 R. Pachociński, Oświata XXI w. Kierunki przeobrażeń, Warszawa 1999, s. 58.

${ }^{66}$ L. Kohlberg, R. Mayer, Rozwój jako cel wychowania, s. 28.

${ }^{67}$ M. Czerepaniak-Walczak, Pedagogika emancypacyjna, s. 128-130.
} 
tomiast, podejmowanie działań zgodnie z krytyczną interpretacją i autorefleksją byłoby możliwe dzięki kompetencjom emancypacyjnym ${ }^{68}$.

Podążając tropami poglądów H. Giroux, który proponuje wielozałożeniową, nieciągłą perspektywę teoretyczną edukacji, w interpretacji koncepcji kształcenia kompetencyjnego konieczne byłoby oparcie się na kilku fundamentach teoretycznych tak, aby unikać ograniczeń każdego z nich. Istotna jakość tez H. Giroux, które stanowią pewną całość i mogą być podstawą do dekonstrukcji omawianego problemu może być skondensowana do zasad:

1) jeśli edukacja stanowi proces tworzenia podmiotów politycznych, to kompetencja do działania ma wymiar krytyczny i emancypacyjny;

2) jeśli etyka jest społecznym dyskursem, to kompetencja oznacza gotowość do podejmowania takiego dyskursu;

3) jeśli tworzone są nowe formy wiedzy, a częściowa epistemologia zastępuje pojęcie obiektywizmu, konstruowane są tym samym nowe przestrzenie uczenia się. Implikuje to rozwój nowych obszarów kompetencji w przestrzeniach do tej pory ignorowanych, np. refleksyjności emocjonalnej. Poznawanie dokonuje się również $\mathrm{w}$ relacjach społecznych, posługując się własnym ciałem, intuicją, emocjami;

4) jeśli kondycja postnowoczesna wymaga łączenia obszarów indywidualnej tożsamości i procesów społecznych, to kompetencje mają znaczenie zarówno społeczne, jak i osobiste ${ }^{69}$.

Skoro: „pedagogia opisuje intelektualne, emocjonalne i etyczne zaangażowania, jakie podejmujemy jako część wysiłków adaptacyjnych, negocjacyjnych i transformacyjnych wobec świata, w którym się znajdujemy"70, to kształcenie kompetencyjne, jeśli w ogóle ma być realizowane, to tylko $\mathrm{w}$ formule krytyczno-refleksyjnej i zdecydowanie wykraczającej poza formalną edukację oraz działania wychowawcze środowiska.

Każda z konstruowanych (pewnie tych pominiętych również) orientacji $\mathrm{w}$ pojmowaniu i kształceniu kompetencji zwraca uwage na inny aspekt funkcjonowania człowieka w odniesieniu do otoczenia. Prawdopodobnie to właśnie od kontekstu będzie zależało, jaki „typ” z repertuaru kompetencji: technicznych, humanistycznych (osobowościowych), czy funkcjonalno-krytycznych będzie regulował zachowania człowieka $\mathrm{w}$ określonej sytuacji. Jednakże, układ kompetencji inklinuje hierarchię nawiązującą do teorii J. Habermasa interesów konstytuujących poznanie, które można traktować

68 Tamże, s. 130.

69 Por. T. Szkudlarek, Pedagogika krytyczna, s. 48.

70 H.A. Giroux, Modernism, Postmodernism, and Feminism. Rethinking the Boundaries of Educational Discourse, College Literature, 1990, 17(2/3), s. 56, za: tamże. 
jako modelowe podstawy edukacji kompetencji ${ }^{71}$. $Z$ tej perspektywy ważne jest przesunięcie zainteresowania $\mathrm{z}$ technicznego (behawioralnego) na osobowościowy (personalistyczny) i funkcjonalny aspekt działań oraz postaw człowieka. Czy tak dzieje się we współczesnych przemianach edukacyjnych?

\section{Kompetencje we współczesnej edukacji}

Tak zwane kompetencje kluczowe, wypracowane w Procesie Bolońskim, wydają się być kolejną, przekonującą listą życzeń głoszącą, jakie kompetencje trzeba posiąść, aby być aktywnym członkiem społeczności: samorealizować się, rozwijać, integrować ze społeczeństwem i aktywnie odnajdować się na rynku pracy ${ }^{72}$. Niepokój budzi fakt, że możemy odczytać kompetencje kluczowe jako zbiór zaleceń, który nie tworzy całościowej struktury. Podana jest lista elementów, którym przypisuje się tę samą ważność, podkreślając wprawdzie istnienie bliżej nie określonych związków. Zalecenie Parlamentu Europejskiego $^{73}$ jest dokumentem prawnym i prawdopodobnie stąd ta oszczędność w opisie kontekstu budowania kompetencji. Ważny wydaje się więc głos w odczytaniu ich z perspektywy wiedzy o edukacji. Refleksyjny praktyk zauważy konieczność wprowadzenia struktury, a przede wszystkim hierarchii. W liście tej nie wyeksponowano czynnika integrującego, dzięki któremu nabywanie, rozwijanie i korzystanie z postulowanych kompetencji miałoby charakter refleksyjny. (De)konstruując ten model, wydaje się, że czynnikiem integrującym jest podmiot, którego "są" kompetencje, który je nabywa.

W modelu kompetencyjnym zwraca się uwagę na zmianę paradygmatu kształcenia z treści na podmiot, powracając tym samym do idei sokratejskich, później oświeceniowych i progresywnych. Jednakże, w umysłach wielu praktyków i teoretyków kształcenie kompetencyjne funkcjonuje jako konstrukt nie tyle złożony, co składający się z zestawu umiejętności nabywanych w różnym stopniu, na różnych etapach edukacji.

Kolejny punkt krytyczny Zalecenia to wyartykułowane oczekiwanie, że systemy edukacyjne będą rozwijać kompetencje i mierzyć efekty. Kompetencje przedstawione wymagają operacjonalizacji, odwołania do określonych zachowań, postaw, umiejętności, wiedzy tak, aby móc je zaobserwo-

\footnotetext{
${ }^{71}$ M. Czerepaniak-Walczak, Pedagogika emancypacyjna, s. 24.

72 Por. Zalecenie Parlamentu Europejskiego i Rady z 18 grudnia 2006 r., s. 393/13.

73 Tamże.
} 
wać i „zmierzyć". Operacjonalizacja niesie jednak wspomniane ryzyko redukcji, uproszczenia struktury kompetencji. Niebezpieczne, bo sprowadzające edukację kolejny raz do kształcenia adaptacyjnych i instrumentalnych umiejętności, jest wskazywanie na listę wyabstrahowanych obszarów wiedzy, działań i umiejętności, bez wyraźnego wyartykułowania związków pomiędzy nimi, hierarchii.

Cechą immanentną kompetencji jest ich dynamizm - są kategorią nigdy nie skończoną, jak sam rozwój. Wydaje się, że każdą kompetencję można poszerzać, przekraczać jej granice. Jednocześnie, zwracając uwagę na strukturę kompetencji, można wskazać na ich rozwój wertykalny: od relatywnie prostych jak kompetencje adaptacyjne, po złożone i nie tak oczywiste, jak krytyczno-emancypacyjne, czy refleksyjność. Otwarta struktura kompetencji powoduje, że mogą stanowić ważny cel edukacji oraz przechodzenia na poziom postkonwencjonalny rozwoju człowieka i konsekwentnie społeczeństwa. Refleksyjność i autonomia charakteryzuje najwyższy etap rozwoju kompetencji, uwarunkowany osobowościowo oraz przez doświadczenie. Ciągłość rozwoju kompetencji do działania implikuje traktowanie wcześniejszych faz rozwoju osobistego jako przygotowania do osiągnięcia autonomii na etapie postkonwencji.

\section{Refleksyjność - najwyższy standard kompetencji}

Jeżeli przyjmiemy, że każde profesjonalne działanie jest oparte na rozumowaniu, należy zgodzić się ze stwierdzeniem, iż to co odróżnia ekspertów od początkujących specjalistów to symboliczna, wynikająca z wnioskowania i zakorzeniona $\mathrm{w}$ doświadczeniu wiedza. $\mathrm{W}$ umysłach ekspertów wiedza jest "skompilowana”, przetworzona i wydaje się, że ekspert nie potrzebuje już świadomej uwagi i refleksji w działaniu. Istnieje nawet zgeneralizowane przekonanie, że bycie ekspertem wymaga natychmiastowej reakcji w każdej sytuacji - automatyzmu działania. Często też poszukujemy specjalistów, którzy niezwłocznie, bez większego zaangażowania intelektualnego udzielą nam pomocy czy informacji. Tak jakby miarą kompetencji była szybkość i trafność reagowania $\mathrm{w}$ określonych sytuacjach. Eksperci budują swoje kompetencje oparte na procesach heurystycznych, które $\mathrm{w}$ połączeniu z wiedzą "naukową" czynią z nich refleksyjnych praktyków. Jeśli pozbawimy możliwości zdobywania wiedzy zdroworozsądkowej, jeśli ją zdyskredytujemy i oderwiemy od stosunków społecznych, to możemy działać mecha- 
nicznie jak komputer, korzystając tylko z repertuaru zaprogramowanych schematów.

Niebezpieczeństwo „niedointerpretowania” kształcenia kompetencyjnego tkwi właśnie w przekonaniu, że kompetencje muszą być tylko praktyczne, muszą służyć sprawnej, obserwowalnej i mierzalnej poprawie jakości działania. Jeśli zaakceptujemy pojęcie kompetencji jako konstruktu teoretycznego, który wyznacza obszary działań edukacyjnych, to powinniśmy nadać mu kontekst raczej funkcjonalno-krytyczny, aniżeli pragmatyczny. Dlaczego? Po pierwsze, wydaje się, że istnieje niewiele czynności, które nie wymagają refleksyjności, czyli takich, w których możemy korzystać z wyuczonych wzorów zachowań, schematów postępowania. Po drugie, coraz częściej sytuacje, w których działamy są na tyle złożone, iż wymagają tej nieustannej uwagi i świadomości. Donald Schon ten stan umysłu człowieka nazwał refleksyjnością, a człowieka, który działa świadomie - refleksyjnym praktykiem ${ }^{74}$.

Idea refleksyjności wyrasta z krytyki uproszczonego rozumienia zależności wiedzy teoretycznej i praktycznego działania (Arystotelesowe wykonywanie - stosowanie wiedzy teoretycznej w praktyce) oraz racjonalności technicznej. J. Habermas określa refleksję jako samookreślenie (self-determination), czyli proces uświadomienia sobie wcześniej przesądzonego kontekstu socjologicznego i ideologicznych ograniczeń, a ponadto przejmowanie kontroli nad tym wpływem ${ }^{75}$. Natomiast J. Dewey rozważa refleksyjność jako stan głębokiego namysłu nad działaniem w odróżnieniu od rutynowego działania. Ciągłe i aktywne rozważania nad przekonaniami, wiedzą „(...) $\mathrm{z}$ różnych stron i w różnym świetle" $\mathrm{w}$ odniesieniu do praktyki i konsekwencji działań ${ }^{76}$. D. Schon podkreśla kategorię zdziwienia i wiedzy intuicyjnej $\mathrm{w}$ działaniu profesjonalnym. Bowiem doświadczenie zdziwienia, zastanowienia się prowadzi do interaktywnego myślenia nad działaniem, jego rezultatami, a także intuicji poznawczej ujawniającej się $\mathrm{w}$ działaniu. Jest to odkrywanie, związanych istotnie z danym działaniem, schematów poznawczych ${ }^{77}$. W takiej sytuacji praktyk, jak badacz, eksperymentuje, poszukuje ukrytego „rozumienia” i zmian w sytuacji i/lub działaniu.

Poczucie sprawstwa jest łatwiej osiągalne na niższych poziomach rozwoju - brak wpływu na otoczenie nawet znaczący, np. w świecie zorganizowa-

${ }^{74}$ D.A. Schon, The reflective practitioner, London 1987, za: D. Gołębniak, Zmiany edukacji nauczycieli. Wiedza - biegłość - refleksyjność, Toruń-Poznań 1998, s. 150-151.

75 D. Carr, Questions of competence, s. 262-263.

76 J. Dewey, Jak myślimy, Warszawa 1988, s. 85.

77 D.A. Schon, The reflective practitioner, s. 150-151. 
nym konwencjonalnie, nie wywołuje dyskomfortu. Paradoksalnie, źródłem doświadczania autonomii, źródłem refleksyjności jest doświadczanie ograniczeń, konieczność domagania się autonomii, bo jest jej żądaniem i przekraczaniem ograniczeń. „Inaczej bowiem człowiek jest zadomowiony w świecie i niezdolny rozpoznać skali swojego zniewolenia czy ograniczeń nieprawomocnie uchodzących za naturalny porządek świata"78.

Refleksyjność kształtuje się w toku powtarzalnego osobistego doświadczenia i ten sposób ujęcia wiedzy i praktyki przez D. Schona bliski jest konstruktywizmowi poznawczemu. Podejście procesualno-strukturalne do budowania wiedzy w znaczący sposób przyczyniło się do myślenia o edukacji właśnie w kategoriach kompetencyjnych. Kompetencje jednostki i konstytuująca je wiedza są efektem aktywnego działania, konstrukcji osoby uczącej się. W ciągłym procesie organizowania i rekonstrukcji własnego obrazu świata jednostka jest w konfrontacji z otoczeniem i samym sobą. Refleksyjność i szlachetna niewiedza ${ }^{79}$ jest więc przejawem najwyższych standardów kompetencji - osiągnięcia postkonwencjonalności rozwoju.

Za sprawą J. Piageta i N. Chomskiego przyjęliśmy zasadę, iż uczenie się przebiega od poznawania poszczególnych elementów, aż do biegłości, abstrakcyjnego zinternalizowania wyszukanych zasad ${ }^{80}$. Odpowiadają temu etapy nabywania kompetencji, a tym najwyższym byłaby refleksyjność i autonomia działania. Jeśli nabywanie kompetencji jest procesem, to kompetencje nie mogą być strukturą zamkniętą, ani zbiorem prostych dyspozycji, ale całością świadczącą o osiągnięciu poziomu postkonwencjonalnego świadomości indywidualnego bycia $\mathrm{w}$ świecie. $\mathrm{W}$ rozumieniu kompetencji pojawia się czynnik ludzki: jeśli fakty, zasady, strategie oraz szybkość i precyzja reakcji miałyby być dowodem na bycie ekspertem - specjalistą w danej dziedzinie - to komputer i sztuczna inteligencja zastępowałyby człowieka nie tylko przy taśmach montażowych i w systemach sterowania, ale również w dziedzinach zarządzania, społecznych, czy innych.

Czy w takim razie kompetencje to kategoria temporalna czy uniwersalna? Czy nie jest tak, że „ubraliśmy” w nowe słowo zawsze obecne pragnienie, aby edukacja "przygotowywała” człowieka do życia ze sobą i innymi?

Wydaje się, że nigdy wcześniej tak wyraźnie nie wyartykułowano i nie uzasadniono potrzeby kształcenia skoncentrowanego na działającym podmiocie po to, by przygotować go do twórczej adaptacji. Nigdy też te deklaracje nie były tak bliskie realizacji. Niestety, interpretując dziejące się prze-

\footnotetext{
78 L. Witkowski, Tożsamość i zmiana, s. 168.

79 B. Pascal, Myśli, przekł. T. Boy-Żeleński, Warszawa 2003.

80 Za: K. Illeris, Trzy wymiary uczenia się, Wrocław 2006, s. 23-24.
} 
miany w płaszczyźnie teoretycznej (ideologicznej) i realizacyjnej wydaje się, że kompetencje kolejny raz sprowadzamy do prostych, obserwowalnych zachowań, praktycznych umiejętności, a nawet odtwarzania wiedzy (np. testy kompetencji, które są tak naprawdę testami wiedzy, osiągnięć szkolnych). Mimo że zwraca się uwagę na nowe wymiary uczenia się, złożoność i wieloaspektowość kompetencji powoduje, iż wprowadzane zmiany mają często charakter powierzchowny i chaotyczny. Niestety, dosyć często można usłyszeć głosy praktyków-malkontentów sparafrazowane do tezy: „nazwijmy to (kompetencje, wiedzę, umiejętności) jak chcą politycy, eksperci, a i tak będziemy robili swoje - czyli tak jak do tej pory".

Kompetencja, kompetencyjność, czy refleksyjność, jakkolwiek nazwiemy opisywane kategorie, są mozaiką umiejętności i doświadczeń, tych kontrolowanych i automatycznych skłonności do działania, nabytych i odkrytych (w sobie), zdolności i predyspozycji, odpowiedzialności i gotowości do dyskursu etycznego. Tak szerokie rozumienie kompetencji przekracza racjonalność kognitywno-instrumentalną i dualizmy teoretycznego - praktycznego, zindywidualizowanego - kolektywnego kształcenia. Łączy w sobie intuicję i rozsądek, doświadczenie i wiedzę, świadomość i nieświadomość, adaptację i świadomość krytyczną. Jeśli edukacja ma rozwijać kompetencje, to refleksyjność, świadomość krytyczna, a nie tylko sprawności działania powinny być celem oddziaływań. Edukacja kompetencyjna to taka edukacja, której: „Rezultatem jest dorosłość pojmowana jako integracja wolności, samodzielności i odpowiedzialności, jako racjonalny, krytyczny sposób bycia w świecie" 81 .

\section{Podsumowanie}

Praktycznym wymiarem krytycznego namysłu nad rolą edukacji w zmianie społecznej (szkoła podążająca za zmianami versus szkoła generująca zmiany) jest odkrywanie napięć pomiędzy postulatami edukacyjnymi a rzeczywistością, również w wymiarze kształcenia kompetencyjnego. Interpretacja tych rozbieżności, w zależności od przyjętej ideologii, prowadzi bądź do adaptacyjnych, bądź emancypacyjnych projektów pedagogicznych. Jeśli przyjmiemy, że cele edukacji są podporządkowane interesom ekonomicznym i praktycznym, to będziemy oczekiwać działań typowo adaptacyjnych i rozwoju kompetencji umożliwiających adaptację. Zgodnie z myślą

${ }^{81}$ M. Czerepaniak-Walczak, Pedagogika emancypacyjna, s. 117. 
krytyczną możemy założyć, że edukacja ma moc rozwijania podmiotowych kompetencji i jest instrumentem zmiany społecznej, więc kompetencje wykraczające poza adaptację są emancypacyjne i krytyczne. Uwzględniając szeroki i zmienny kontekst edukacji, coraz częściej dystansujemy się (przynajmniej $w$ rozważaniach naukowych) od definiowania celów edukacji w akontekstualnych kategoriach sprawności, technologii, czy rzemiosła typowych dla orientacji instrumentalnej, racjonalności technicznej. Dylematy kształcenia kompetencyjnego obecne są więc na poziomie epistemologicznym, ontologicznym, a nie tylko praktycznym.

Nie sposób w teorii edukacji, jak i pedagogii unikać myślenia normatywnego. Trudno unikać sformułowań: powinno się..., należy..., niezbędne jest, aby... w edukacji. Mogą one wskazywać na autorytaryzm myślenia pedagogicznego, ale również określać granice działań pedagogicznych. Dlatego wydaje się, że "powinno się" w dyskursie edukacyjnym dopuszczać wielość głosów, wielość ideologii i różnorodność przestrzeni rozwoju. Toteż, kompetencje krytyczne i emancypacyjne stanowią szeroką ramę interpretacji kompetencji człowieka. Konsekwentnie nie jest możliwe osiągnięcie ciągłości w zestawach kompetencji, osiągnięcie pewnej kategorii kompetencji, np. merytorycznych nie jest warunkiem niezbędnym i wystarczającym do przechodzenia na wyższe poziomy rozwoju. Wszystkie wymienione powyżej kategorie kompetencji stanowią o jakości działania (i życia!) człowieka, mówiąc truistycznie - są "potrzebne”, ale osiągnięcie adaptacji nie jest ostatecznym celem, ale raczej przekraczanie ograniczeń, odwaga mówienia "głosem", osiąganie wolności. Tak interpretowane kompetencje wpisują się w rozwój osobowy jednostki, rozwój społeczny, które dążą do postkonwencji. Artykułowane kształcenie kompetencyjne jest zredukowane do kształcenia instrumentalnego; powinno to budzić obawę, że wyższe pułapy uczenia się i rozwoju społecznego nie zostaną odblokowane ${ }^{82}$.

Wydaje się, że szkoła realizuje zredukowany model kompetencji i posługując się słowami J. Staniszkis - realizuje rzeczywistość założeniową83. Kompetencyjne kształcenie to nie behawioralne kształcenie umiejętności "potrzebnych", użytecznych w życiu, to nie odchodzenie od kształcenia poznawczego na rzecz działaniowego, to nie realizowanie indywidualnych potrzeb uczniów (bo to w szkole, niestety, niemożliwe). Kształcenie kompetencji do działania (nauki, pracy, współdziałania) to istota edukacji do krytycznej adaptacji i zmiany, nie może pomijać jednak płaszczyzny instrumentalnych kompetencji. Brak aspektów działaniowych w kształconych kompetencjach,

82 L. Witkowski, Tożsamość i zmiana, s. 161-162.

${ }^{83}$ J. Staniszkis, Ontologia realnego socjalizmu (pierwsze przybliżenie), Krytyka, 1987, 26. 
takich jak komunikowanie się, rozwiązywanie konfliktów czy kompetencji intrapersonalnych, niesie z sobą ryzyko zachowań nieadekwatnych, a nawet destrukcyjnych.

Napięcia wynikające ze zmian cywilizacyjnych poszerzają tzw. lukę ludzką, czyli nieadekwatność zachowań ludzkich wobec zagrożeń i napięćc4. Czy kształcenie kompetencyjne może tę lukę „zewrzeć"? W kształcie obecnym edukacja ani nie adaptuje, ani nie emancypuje: utrudnia stawanie się podmiotem, osiąganie krytyczności myślenia, a przekonanie, że szkoła jest miejscem wszechstronnego rozwoju jest mitem ${ }^{85}$. Redukcja tej rozbieżności jest bardziej prawdopodobna, jeśli faktycznie nastąpi przejście w edukacji od kultury przedmiotów do kultury podmiotów ${ }^{86}$ również $\mathrm{w}$ rozumieniu kształcenia kompetencyjnego. Kompetencje mogłyby być potencjałem emancypacyjnym odrzucającym bierność, konformizm i konwencjonalne pełnienie ról. Jednak bez zmiany poziomu uczenia się, które powinno przygotowywać do działania, a nie tylko do dostosowania i reprodukowania, szkoła pozostanie tylko "mitycznym” miejscem rozwoju. Odwołując się do tez Lecha Witkowskiego, system edukacji w powiązaniu z innymi układami społecznymi, przyjmując za obowiązującą tożsamość konwencjonalną, może blokować przechodzenie na wyższe poziomy kompetencji, dlatego też realizacja idei kształcenia kompetencyjnego ma sens jeśli umocowana jest w teorii krytycznej społecznie ${ }^{87}$. W takim ujęciu kompetencje są rozumiane jako kompetencje do działania, krytycznego myślenia, podejmowania aksjologicznie umocowanych wyborów, dochodzenia do postkonwencjonalności w rozwoju ${ }^{88}$.

O efektach kształcenia kompetencyjnego rozstrzyga nie tyle wyrafinowane odniesienie teoretyczne (to prezentowane $\mathrm{w}$ strategii bolońskiej jest w gruncie rzeczy bardzo pragmatyczne) czy strategia oddziaływań edukacyjnych, co tożsamość instytucji te działania podejmującej, wyrażającej się tym, jaki zakłada wariant świata i typ tożsamości człowieka ${ }^{89}$. Wydaje się więc, że kultura edukacyjna szkoły niezredukowana do racjonalności technologicznej, realizująca komunikacyjny model relacji pedagogicznej i przede wszystkim nie poszukująca powszechnych zasad czy pewności, ma znacznie

${ }^{84}$ J.W. Botkin, M. Elmandjra, M. Maltiza, Uczyć się - bez granic. "Jak zewrzeć lukę ludzką?" Raport Klubu Rzymskiego, Warszawa 1982, s. 50.

85 M. Dudzikowa, Mit o szkole jako "miejscu wszechstronnego" rozwoju ucznia, Kraków 2004.

86 K. Obuchowski, Mikroświat i makroświat człowieka, Przegląd Humanistyczny, 1988, 4-5, s. 59.

87 L. Witkowski, Tożsamość i zmiana, s. 129.

${ }^{88}$ L. Kohlberg, R. Hersh, Moral development - a review of theory, s. 53-59.

${ }^{89}$ Por. tamże, s. 172. 
większe szanse na kształcenie kompetencji do działania, aniżeli szkoła, która chce mierzyć efekty kształcenia.

\section{BIBLIOGRAFIA}

Bauman Z., Ponowoczesne wzory osobowe, Studia Socjologiczne, 1993, 2.

Botkin J.W., Elmandjra M., Malitza M., Uczyć się - bez granic. "Jak zewrzeć lukę ludzką?" Raport Klubu Rzymskiego, PWN, Warszawa 1982.

Carr D., Questions of competence, British Journal of Educational Studies, 1995, 41(3).

Chomsky N., Aspects of the theory of syntax, MIT Press, Cambridge 1965.

Czerepaniak-Walczak M., Pedagogika emancypacyjna, Gdańskie Wydawnictwo Psychologiczne, Gdańsk 2006.

Dąbrowski K., Dezintegracja pozytywna, Państwowy Instytut Wydawniczy, Warszawa 1979.

Delors J., Edukacja: jest w niej ukryty skarb, Wydawnictwo UNESCO, Warszawa 1998.

Dewey J., Demokracja $i$ wychowanie, Ossolineum, Wrocław-Warszawa-Kraków-Gdańsk 1972.

Dewey J., Jak myślimy, PWN, Warszawa 1988.

Dudzikowa M., Mit o szkole jako miejscu "wszechstronnego rozwoju” ucznia, Oficyna Wydawnicza Impuls, Kraków 2004.

Evert G., Habermas i edukacja, [w:] Nieobecne dyskursy, cz. III, red. Z. Kwieciński, Uniwersytet Mikołaja Kopernika, Torun 1993.

Freire P., Pedagogy of freedom. Ethics, Democracy, and Civic Courage, Rowan and Littlefield Publication, Lanham 2001.

Gałdowa A. (red.), Tożsamość człowieka, Wydawnictwo UJ, Kraków 2000.

Garz D., Lawrence Kohlberg - Introduction, Barbara Budrich Publishers, Leverkusen 2009.

Giroux H.A., Modernism, Postmodernism, and Feminism. Rethinking the Boundaries of Educational Discourse, College Literature, 1990, 17(2/3).

Gołębniak D., Zmiany edukacji nauczycieli. Wiedza - biegłość - refleksyjność, Wydawnictwo Edytor, Toruń-Poznań 1998.

Habermas J., Teoria działania komunikacyjnego. Racjonalność działania a racjonalność społeczna, t. 1, przekł. A.M. Kaniowski, PWN, Warszawa 1999.

Habermas J., Teoria i praktyka: wybór pism, przekł. M. Łukasiewicz, Z. Krasnodębski, Państwowy Instytut Wydawniczy, Warszawa 1983.

Hessen S., Podstawy pedagogiki, Wydawnictwo Akademickie Żak, Warszawa 1997.

Illeris Z., Trzy wymiary uczenia się, Wydawnictwo Naukowe DSW, Wrocław 2006.

Kohlberg L., Mayer R., Rozwój jako cel wychowania, [w:] Alternatywy myślenia o/w edukacji, red. Z. Kwieciński, Instytut Badań Edukacyjnych, Warszawa 2000.

Kohlberg L., Hersh R., Moral development - a review of theory, Theory into Practice, 1977, $16(2)$.

Kossowska M., Sołtysińska I., Szkolenia pracowników a rozwój organizacji, Oficyna Ekonomiczna, Kraków 2002.

Kozielecki J., Człowiek wielowymiarowy, Wydawnictwo Akademickie Żak, Warszawa 1996.

Kozielecki J., Koncepcje psychologiczne człowieka, Wydawnictwo Akademickie Żak, Warszawa 1980. 
Kwaśnica R., Wprowadzenie do myślenia. O wspomaganiu nauczyciela w rozwoju, Studia Pedagogiczne, 1995, 61.

Kwiatkowska H., Orientacje w kształceniu nauczycieli, WSiP, Warszawa 1988.

Kwiatkowska H., Pedeutologia, WAiP Warszawa 2008.

Madalińska-Michalak J.M., Góralska R., Kompetencje emocjonalne nauczyciela, Wydawnictwo Wolters Kluwer Business ABC, Warszawa 2012.

Maslow A., Motywacja i osobowość, Wydawnictwo Naukowe PWN, Warszawa 2010.

Melosik Z., Uniwersytet i społeczeństwo. Dyskurs wolności, wiedzy i władzy, Oficyna Wydawnicza Impuls, Kraków 2009.

Możdżeń S.I., Historia wychowania, t. 1, Wydawnictwo Pedagogiczne ZNP, Sandomierz 2006.

Obuchowski K., Mikroświat i makroświat człowieka, Przegląd Humanistyczny, 1988, 4-5.

Pachociński R., Oświata XXI w. Kierunki przeobrażeń, IBE, Warszawa 1999.

Pascal B., Myśli, przekł. T. Boy-Żeleński, Wydawnictwo Zielona Sowa, Warszawa 2003.

Schon D.A., The reflective practitioner, Routledge, London 1987.

Staniszkis J., Ontologia realnego socjalizmu (pierwsze przyblizenie), Krytyka, 1987, 26.

Szkudlarek T., Pedagogika krytyczna, [w:] Wyzwania pedagogiki krytycznej i antypedagogiki, red. T. Szkudlarek, B. Śliwerski, Oficyna Wydawnicza Impuls, Kraków 2000.

Thorne B., Rogers C., Twórcy psychoterapii, przekł. E. Wojtych, Gdańskie Wydawnictwo Psychologiczne, Gdańsk 2006.

Tomaszewski T., Podstawowe formy organizacji i regulacji zachowania, [w:] Psychologia, red. T. Tomaszewski, PWN, Warszawa 1978.

White R., Motivation reconsidered - the concept of competence, Psychological Review, 1959, 66(5).

Witkowski L., Interesy konstytuujące poznanie, [w:] Kierunki filozofii wspótczesnej, t. II, red. J. Pawlak, Wydawnictwo UMK, Torun 1995.

Witkowski L., Rozwój i tożsamość w cyklu życia. Studium koncepcji E.H. Eriksona, Wydawnictwo J. Witkowicz, Torun 2000.

Witkowski L., Tożsamość i zmiana. Epistemologia i rozwojowe profile w edukacji, Wydawnictwo Naukowe DSW, Wrocław 2010.

Zalecenie Parlamentu Europejskiego i Rady z 18 grudnia 2006 r. w sprawie kompetencji kluczowych w procesie uczenia się przez całe życie, źródło: http://eurlex.europa.eu/LexUriServ/LexUriServ.do?uri=OJ:L:2006:394:0010:0018:pl:PDF [dostęp, 11.XII. 2011]. 
